\title{
PENGARUH UKURAN PERUSAHAAN, PROFITABILITAS, SOLVABILITAS, KUALITAS AUDIT, OPINI AUDIT, KOMITE AUDIT TERHADAP AUDIT REPORT LAG
}

\author{
Ni Made Sunarsih ${ }^{1}$, Ida Ayu Budhananda Munidewi ${ }^{2}$, Ni Kadek Mirah Masdiari ${ }^{3 *}$ \\ 1,2,3 Fakultas Ekonomi dan Bisnis Universitas Mahasaraswati Denpasar \\ *e-mail: sunarsihnimade@,gmail.com
}

DiPublikasi: 01/07/2021

https://doi.org/10.22225/kr.13.1.2021.1-13

\begin{abstract}
Audit report lag is the time span required to complete the audit conducted by the auditor as measured by the time difference between the date of the financial statements and the date of the audit opinion in the financial statements. The length of time it takes for the auditor to audit the company's financial statements can have an impact on decision making by various parties. Therefore, financial reports must be presented accurately and in a timely manner so that they are more useful for those who need information. The purpose of this study was to determine the effect of company size, solvency, profitability, audit quality, audit opinion and audit committee on audit report lag.

This research was conducted at mining companies listed on the Indonesia Stock Exchange 2016-2018. The type of data used is quantitative data in the form of audited financial reports along with notes on financial reports and qualitative data in the form of mining company data. The sample used was 41 companies with a total of 123 observations, with a purposive sampling method. The analysis technique used is multiple linear regression analysis.

The result showed that company size has a positive effect on audit report lag. Solvency and audit quality have a negative effect on the audit report lag. Profitability, audit opinion, and audit committee have no effect on the audit report lag. Further research can develop this research by using other variables which theoretically have an effect on the audit report lag, such as changes in auditors and the board of commissioners.
\end{abstract}

Keywords: Audit report lag, company size, profitability, solvency, audit quality, audit opinion, audit

\begin{abstract}
Abstrak
Keterlambatan laporan audit adalah rentang waktu yang diperlukan untuk menyelesaikan audit yang dilakukan oleh auditor yang diukur dari selisih waktu antara tanggal laporan keuangan dan tanggal opini audit dalam laporan keuangan. Lamanya waktu yang dibutuhkan auditor untuk mengaudit laporan keuangan perusahaan dapat berdampak pada pengambilan keputusan oleh berbagai pihak. Oleh karena itu, laporan keuangan harus disajikan secara akurat dan tepat waktu agar lebih bermanfaat bagi yang membutuhkan informasi. Tujuan penelitian ini adalah untuk mengetahui pengaruh ukuran perusahaan, solvabilitas, profitabilitas, kualitas audit, opini audit dan komite audit terhadap audit report lag.

Penelitian ini dilakukan pada perusahaan pertambangan yang terdaftar di Bursa Efek Indonesia tahun 2016-2018. Jenis data yang digunakan adalah data kuantitatif berupa laporan keuangan auditan beserta catatan atas laporan keuangan dan data kualitatif berupa data perusahaan pertambangan. Sampel yang digunakan adalah 41 perusahaan dengan jumlah observasi 123, dengan metode purposive sampling. Teknik analisis yang digunakan adalah analisis regresi linier berganda.

Hasil penelitian menunjukkan bahwa ukuran perusahaan berpengaruh positif terhadap audit report lag. Solvabilitas dan kualitas audit berpengaruh negatif terhadap keterlambatan laporan audit. Profitabilitas, opini audit, dan komite audit tidak berpengaruh terhadap keterlambatan laporan audit. Penelitian selanjutnya dapat mengembangkan penelitian ini dengan menggunakan variabel lain yang secara teoritis berpengaruh terhadap audit report lag, seperti perubahan auditor dan dewan komisaris.
\end{abstract}

Kata Kunci : Audit report lag, ukuran perusahaan, profitabilitas, solvabilitas, kualitas audit, opini audit, audit

\section{PENDAHULUAN}

Berdasarkan undang-undang Nomor 8 tahun 1995 tentang pasar modal, Bursa Efek Indonesia (BEI) adalah pihak yang ditetapkan pemerintah untuk menyelenggarakan dan menyediakan sistem atau sarana untuk mempertemukan penawaran jual- beli atas efek-efek yang lain dengan tujuan memperdagangkan efek diantara mereka. Laporan keuangan merupakan salah satu bentuk tanggung jawab pengelolaan perusahaan yang dilakukan oleh manajemen atas sumber daya yang dipercayakan 
kepadanya dan dikomunikasikan kepada pihak yang berkepentingan terhadap laporan keuangan serta bermanfaat untuk pengambilan keputusan strategis bagi perusahaan.

Sesuai PSAK No. 1 pada Kerangka Dasar Penyusunan dan Penyajian Laporan Keuangan paragraf 43 bahwa jika terdapat penundaan yang tidak semestinya dalam pelaporan, maka informasi yang dihasilkan akan kehilangan relevansinya. Pemanfaatan laporan keuangan dapat dinilai dari ketepatan waktu pelaporan keuangan perusahaan. Keterlambatan dalam pelaporan keuangan dapat disebabkan oleh terjadinya proses audit yang dilakukan oleh auditor, dimana tiap perusahaan membutuhkan jumlah hari yang dibutuhkan oleh auditor dalam menyelesaikan prosedur auditnya. Jumlah hari yang dibutuhkan auditor dalam menyelesaikan prosedur auditnya disebut dengan audit report lag.

(Saputri, 2014) mendefinisikan audit report lag sebagai lama waktu penyelesaian audit yang dilaksanakan oleh auditor dilihat dari perbedaan tanggal tutup tahun buku laporan keuangan (biasanya 31 Desember) sampai dengan tanggal opini audit dalam laporan keuangan auditan.

Peraturan Otoritas Jasa Keuangan Nomor 29/POJK.04/2016 pasal 7 disebutkan tentang laporan tahunan emiten atau perusahaan publik dimana emiten atau perusahaan publik wajib menyampaikan laporan tahunan kepada Otoritas Jasa Keuangan paling lambat pada akhir bulan keempat setelah tahun buku berakhir. Dengan batas waktu yang ditetapkan oleh OJK tersebut, perusahaan di wajibkan untuk melaporkan laporan keuangan yang telah di audit dalam batas waktu 120 hari, hal tersebut mengharuskan perusahaan dan KAP untuk menyusun strategi supaya laporan keuangan auditan dapat keluar tepat waktu, mengingat bahwa proses audit memerlukan waktu yang tidaklah singkat. Audit report lag dapat dipengaruhi oleh beberapa faktor antara lain ukuran perusahaan, profitabilitas, solvabilitas, kualitas audit, opini audit dan komite audit.

Ukuran perusahaan dapat menentukan tingkat kemudahan perusahaan memperoleh dana dari pasar modal. Hasil penelitian (Chasanah \& Sagoro, 2017) menyatakan ukuran perusahaan yang dinilai dari total aset memiliki pengaruh negatif terhadap audit report lag. Hal ini dapat diartikan bahwa semakin besar ukuran suatu perusahaan maka audit report lag semakin singkat. Perusahaan besar biasanya sudah memiliki sistem pengendalian internal yang baik. Hal ini akan memudahkan auditor dalam menyelesaikan pekerjaannya. Berbeda dengan pendapat (Delia Alvorina Kalinggajaya, 2018), yang menyatakan ukuran perusahaan mempunyai pengaruh positif terhadap audit report lag.

Profitabilitas ini digunakan untuk mengukur tingkat imbalan atau perolehan (keuntungan) dibanding penjualan atau aktiva. Profitabilitas mengukur seberapa besar kemampuan perusahaan memperoleh laba dalam hubungan dengan penjualan, aktiva maupun laba dan modal sendiri (Sujarweni, 2017). Hasil penelitian (Chasanah \& Sagoro, 2017) dan (Delia Alvorina Kalinggajaya, 2018)menyatakan bahwa variabel profitabilitas tidak berpengaruh terhadap audit report lag. Variabel profitabilitas tidak berpengaruh terhadap audit report lag dikarenakan semua perusahaan, baik yang memiliki profitabilitas tinggi maupun rendah sama-sama mempunyai kewajiban untuk menyampaikan laporan keuangannya secara tepat waktu. Sementara penelitian dari (Sastrawan \& Latrini, 2016) menunjukan bahwa profitabilitas berpengaruh negatif terhadap audit report lag. Hasil penelitian yang menunjukkan bahwa profitabilitas berpengaruh negatif terhadap audit report lag mengindikasikan bahwa perusahaan yang mendapatkan profit yang besar cenderung melakukan proses audit lebih singkat dibanding perusahaan yang mengalami profit yang kecil. Hal ini dikarenakan perusahaan yang memperoleh laba lebih besar tidak ada alasan untuk menunda penerbitan laporan keuangan audit bahkan cenderung untuk mempercepat penerbitan laporan keuangan audit, karena perusahaan yang mengalami laba yang lebih besar akan menarik minat calon investor untuk membeli saham sehingga akan menyebabkan kenaikan harga saham.

Solvabilitas menunjukkan kemampuan perusahaan untuk memenuhi segala kewajiban finansialnya pada saat perusahaan di likuidasi. Hasil penelitian dari (Pramaharjan \& Cahyonowati, 2015), (Chasanah \& Sagoro, 2017) menunjukkan bahwa solvabilitas berpengaruh negatif dan tidak signifikan terhadap audit report lag. Hasil penelitian menyatakan bahwa kemampuan perusahaan untuk memenuhi seluruh kewajibannya tidak mempunyai pengaruh yang signifikan terhadap audit report lag. Hal ini dikarenakan auditor dalam menyelesaikan audit laporan 
keuangan tetap sesuai dengan prosedur yang telah diatur dalam Standar Profesional Akuntan Publik (SPAP). Oleh karena itu, auditor pasti telah memperhitungkan waktu dan kemampuan untuk melakukan proses pengauditan utang perusahaan. Auditor juga tidak membutuhkan waktu yang lama untuk menyelesaikan proses audit ketika pihak manajemen perusahaan dapat menjelaskan alasan tingginya proporsi utang perusahaan terhadap aset yang dimiliki. (Sastrawan \& Latrini, 2016) menyatakan bahwa solvabilitas berpengaruh positif terhadap audit report lag mengindikasikan bahwa tingginya jumlah hutang yang dimiliki perusahaan akan menyebabkan proses audit yang relatif lebih panjang. Proporsi hutang terhadap total aktiva yang tinggi juga mungkin membuat auditor perlu meningkatkan kehati-hatian dan kecermatan yang lebih dalam pengauditan terkait dengan masalah kelangsungan perusahaan.

Kualitas audit adalah karakteristik atau gambaran praktik dan hasil audit berdasarkan standar auditing dan standar pengendalian mutu yang menjadi ukuran pelaksanaan tugas dan tanggung jawab profesi seorang auditor. (Karang et al., 2015) menyatakan bahwa, kualitas audit berpengaruh negatif pada audit delay. Kualitas jasa audit dari suatu KAP tentunya akan berimbas pada rentang waktu penyelesaian audit, reputasi KAP akan terjaga apabila KAP mampu memberikan kualitas jasa terbaik yang dibarengi dengan waktu penyelesaian audit yang cepat. Sementara penelitian (Sabatini \& Vestari, 2019) menyatakan kualitas audit tidak berpengaruh terhadap audit report lag.

Opini audit adalah pernyataan standar dari kesimpulan auditor yang didapatkan berdasarkan kesimpulan dari proses audit (Arens, A, Elder, Randal J, Beasley, Mark S, dan Jusuf, 2011).

\section{TINJAUAN PUSTAKA}

\section{Teori Agensi}

Teori agensi merupakan teori yang digunakan oleh perusahaan dalam melihat hubungan manajemen dan pemilik modal terhadap proses menjalankan bisnisnya. Hubungan agensi muncul ketika satu orang atau lebih (principal) mempekerjakan orang lain (agent) untuk memberikan suatu jasa yang kemudian mendelegasikan wewenang pengambilan keputusan kepada agen tersebut. Ketika pemegang saham menunjuk manajer atau agen sebagai pengelola dan pengambil keputusan bagi
Penelitian yang dilakukan oleh Andika (2015) menyatakan opini audit berpengaruh negatif pada audit report lag. Hal ini berarti perusahaan yang menerima qualified opinion menunjukkan audit delay yang lebih panjang dibanding yang menerima unqualified opinion. Berbeda dengan penelitian yang dilakukan oleh (Apitaningrum, 2017), (Tiono \& JogiC, 2013) menyatakan Opini audit tidak memiliki pengaruh yang signifikan terhadap audit report lag.

Komite Audit adalah salah satu komite yang dibentuk oleh dewan komisaris dan bertanggung jawab kepada dewan komisaris dengan tugas dan tanggung jawab utama untuk memastikan prinsipprinsip diterapkan secara konsisten dan memadai oleh para eksekutif. Dalam penelitian (Isnania et al., 2018) menyatakan Komite audit berpengaruh negatif terhadap audit report lag. Tetapi berbeda dengan penelitian Arisha (2019) yang menyatakan komite audit tidak berpengaruh terhadap audit report lag, dikarenakan bahwa penambahan satu anggota tidak berpengaruh terhadap jalannya proses komite audit. Komite audit yang memiliki tiga anggota dengan komite audit yang memiliki empat anggota bukan menjadi salah satu faktor terjadinya audit report lag yang lama.

Dari beberapa penelitian yang disebutkan di atas terdapat ketidakkonsistenan terhadap hasil penelitian terkait dengan audit report lag yang menjadi variabel dependen, Penelitian ini dilakukan untuk menemukan apakah terdapat pengaruh ukuran perusahaan, profitabilitas, solvabilitas, kualitas audit, opini audit dan komite audit berpengaruh terhadap audit report lag pada perusahaan sektor pertambangan yang terdaftar di Bursa Efek Indonesia periode 2016-2018.

perusahaan, maka pada saat itulah hubungan keagenan muncul. Jensen dan (Jensen \& Meckling, 1976) juga menyatakan bahwa masalah agensi disebabkan karena terjadinya konflik kepentingan dan asimetri informasi antara principal dan agen.

\section{Teori Kepatuhan}

Teori Kepatuhan didefinisikan oleh (Chaplin, 2014) sebagai pemenuhan, mengalah tunduk dengan kerelaan; rela memberi, menyerah, mengalah; membuat suatu keinginan konformitas sesuai dengan harapan atau kemauan orang lain. Dalam 
kepatuhan yang dinilai adalah ketaatan semua aktivitas sesuai dengan kebijakan, aturan, ketentuan dan undang-undang yang berlaku. Sedangkan kepatutan lebih pada keluhuran budi pimpinan dalam mengambil keputusan. Jika melanggar kepatutan belum tentu melanggar kepatuhan. Selain itu, kepatuhan menentukan apakah pihak yang di audit telah mengikuti prosedur, standar, dan aturan tertentu yang ditetapkan oleh pihak yang berwenang.

\section{Audit Report Lag}

Perkembangan pasar modal di Indonesia yang semakin pesat ditandai dengan semakin banyaknya perusahaan yang menjual sahamnya di pasar modal dan peningkatan tersebut diikuti dengan semakin dibutuhkannya laporan keuangan sebagai sumber informasi bagi pasar dan investor dalam mengambil keputusan. Dengan semakin banyak perusahaan yang go public mengharuskan perusahaan untuk menyampaikan laporan keuangan secara tepat waktu, supaya informasi perusahaan relevan dan dapat digunakan sebagai sumber informasi bagi pengambilan keputusan. Salah satu faktor yang dapat mempengaruhi ketepatan waktu dalam pelaporan keuangan adalah audit report lag.

\section{Standar Audit}

Standar Audit (SA) mengatur tentang standar yang digunakan oleh praktisi saat melaksanakan kegiatan audit atas laporan keuangan historis. Dilakukannya adopsi standar internasional yang ditetapkan oleh IFAC membuat standar audit pada SPAP 31 Maret 2011 yang selama ini digunakan dengan berbasis US GAAS, berubah menjadi SPAP berbasis International Standard on Auditing (ISA). SPAP berbasis standar internasional, khususnya standar auditing untuk emiten sudah berlaku efektif untuk periode yang dimulai pada atau setelah tanggal 1 Januari 2013, dan 1 Januari 2014 untuk entitas selain emiten. Berbeda dengan standar audit sebelumnya, SPAP berbasis ISA tidak membagi standar audit ke dalam tiga kategori yakni, Standar Umum, Standar Pekerjaan Lapangan, dan Standar Pelaporan. Namun standar-standar yang disajikan dalam SPAP berbasis ISA sudah mencerminkan proses pengerjaan auditing yang dibagi ke dalam enam bagian dan 36 standar.

\section{Ukuran Perusahaan}

Ukuran perusahaan menunjukan besar kecilnya sebuah perusahaan. Suatu perusahaan dapat dikatakan besar atau kecil dilihat dari beberapa sudut pandang seperti total nilai aset, total penjualan, jumlah tenaga kerja dan sebagainya menurut (Tiono \& JogiC, 2013). Ukuran perusahaan adalah skala perusahaan yang dilihat dari total aktiva perusahaan pada akhir tahun. Total penjualan juga dapat digunakan untuk mengukur besarnya perusahaan. Ukuran perusahaan menggambarkan besar kecilnya perusahaan. Besar kecilnya usaha tersebut ditinjau dari lapangan usaha yang dijalankan.

\section{Profitabilitas}

Profitabilitas adalah kemampuan suatu perusahaan untuk mendapatkan laba dalam periode tertentu. Profitabilitas merupakan kemampuan perusahaan menghasilkan laba yang akan menjadi dasar pembagian dividen perusahaan. Ketika perusahaan mendapatkan laba (profit), maka perusahaan cenderung untuk melaporkan laporan keuangannya lebih cepat dibandingkan dengan perusahaan yang mengalami kerugian karena adanya tuntutan untuk melaporkan kepada publik posisi perusahaan yang sedang baik. Indikator yang digunakan untuk menilai profitabilitas perusahaan adalah ROA (return on asset).

\section{Solvabilitas}

Solvabilitas merupakan kemampuan perusahaan untuk membayar semua hutangnya baik jangka pendek maupun panjang seandainya perusahaan di likuidasi. Perusahaan yang mampu melunasi hutangnya setelah di likuidasi dianggap perusahaan yang solvabel. Sebaliknya, semakin tinggi rasio utang terhadap total aktiva, maka perusahaan dianggap memiliki kesulitan dalam membayar hutang-hutang yang dimiliki atau disebut tidak solvabel. Perusahaan yang kesulitan dalam membayar hutang yang dimiliki atau perusahaan yang tidak solvabel cenderung tidak patuh untuk melaporkan laporan keuangan secara tepat waktu. Kesulitan ekonomi yang dialami perusahaan juga dianggap sebagai bad news bagi investor sehingga perusahaan akan menunda untuk melaporkan kondisi keuangannya. Indikator yang digunakan untuk mengukur tingkat solvabilitas suatu perusahaan adalah total debt to assets rasio.

\section{Kualitas audit}

Kualitas audit adalah probabilitas dimana seorang auditor menemukan dan melaporkan tentang adanya suatu pelanggaran dalam sistem akuntansi auditeenya. Salah satu alat untuk menilai kualitas audit adalah ukuran KAP (Kantor Akuntan Publik). 
Pada umumnya, KAP besar (bekerja sama dengan KAP internasional) memperoleh insentif yang lebih besar dan mempunyai lebih banyak sumber daya sehingga tugas audit dapat dilaksanakan secara lebih efisien dan efektif, serta memiliki fleksibilitas yang lebih tinggi dalam penjadwalan audit. Kantor Akuntan Publik adalah suatu bentuk organisasi akuntan publik yang memperoleh izin sesuai dengan perundang-undangan, yang berusaha di bidang pemberian jasa profesional dalam praktek akuntan publik.

\section{Opini Audit}

Menurut (Arens, A, Elder, Randal J, Beasley, Mark S, dan Jusuf, 2011) opini audit adalah pernyataan standar dari kesimpulan auditor yang didapatkan berdasarkan kesimpulan dari proses audit. Setelah diterbitkannya laporan audit, terdapat beberapa potensi komunikasi auditor dengan pegawai klien. Hasil komunikasi dengan klien dapat menunjukan hasil yang positif dan negatif. Hasil positif tercapai apabila terdapat kesepakatan langsung antara klien dengan auditor sedangkan hasil negatif terjadi apabila terjadi ketidaksepakatan dengan klien. Jangka waktu proses penyelesaian audit dapat berbeda satu dengan lainnya antara perusahaan yang memperoleh pendapat wajar tanpa syarat dengan pendapat audit lainnya (pendapat wajar dengan syarat, tidak wajar dan tidak memberikan pendapat). Perusahaan yang memperoleh pendapat wajar tanpa syarat akan cenderung lebih ringkas rentang waktunya dibanding dengan pendapat lainnya. Menurut Instutit Akuntan Publik Indonesia (IAPI) Standar Audit "(SA)" 700 dan 705 ada empat jenis pendapat akuntan, yaitu Opini wajar tanpa pengecualian, pendapat wajar dengan pengecualian (Qualified Opinion), pendapat tidak wajar (Adverse Opinion), pernyataan tidak memberikan pendapat (Disclaimer Opinion).

\section{Komite audit}

Komite audit merupakan sebuah komite yang dibentuk oleh dewan komisaris dengan bertujuan untuk membantu komisaris independen dalam menjalankan tugas dan tanggung jawab pengawasan dalam pelaporan keuangan. Komite audit bertugas untuk memantau perencanaan dan pelaksanaan kemudian mereka mengevaluasi hasil audit guna menilai kelayakan dan kemampuan pengendalian internal termasuk proses penyusunan laporan keuangan. Berdasarkan peraturan Otoritas Jasa Keuangan Nomor 55/POJK 04/2015 tentang pembentukan dan pedoman pelaksanaan kerja komite audit mengatakan bahwa seluruh perusahaan go public di wajibkan untuk membuat komite audit paling tidak beranggotakan 3 orang yang terdiri atas satu orang sebagai ketua dan dua orang lainnya sebagai anggota komite audit (Rizkyllah, 2018).

\section{Hipotesis}

\section{Pengaruh Ukuran Perusahaan Terhadap Audit Report Lag}

Variabel ukuran perusahaan dapat diartikan sebagai suatu gambaran dimana perusahaan masuk dalam kategori perusahaan besar atau perusahaan kecil dengan berbagai cara diantaranya dinyatakan berdasarkan total aset, nilai pasar saham, dan lainlain. Pada penelitian ini ukuran perusahaan akan diukur berdasarkan besarnya total aset yang dimiliki oleh perusahaan.

Ukuran perusahaan diperkirakan menjadi salah satu sebab panjang pendeknya publikasi laporan keuangan. Perusahaan yang besar cenderung memiliki tingkat audit report lag yang lebih pendek. Hal ini sesuai dengan penelitian yang dilakukan oleh (Chasanah \& Sagoro, 2017) menyatakan ukuran perusahaan berpengaruh negatif terhadap audit report lag. Sejalan dengan penelitian (Pramaharjan \& Cahyonowati, 2015) yang menyatakan ukuran perusahaan berpengaruh negatif terhadap audit report lag.

H1: Ukuran perusahaan berpengaruh negatif terhadap audit report lag Pengaruh Profitabilitas Terhadap Audit Report Lag

Profitabilitas menunjukan keberhasilan perusahaan dalam menghasilkan keuntungan. Dengan demikian dapat dikatakan bahwa profit merupakan berita baik bagi perusahaan. Perusahaan tidak akan menunda penyampaian informasi yang berisi berita baik. Perusahaan yang memiliki tingkat profitabilitas yang tinggi akan membutuhkan waktu dalam pengauditan laporan keuangan lebih cepat dikarenakan keharusan untuk menyampaikan kabar baik secepatnya kepada publik. Mereka juga memberikan alasan bahwa auditor yang menghadapi perusahaan yang mengalami kerugian memiliki respon yang cenderung lebih berhati-hati dalam melakukan proses pengauditan. Jika perusahaan menghasilkan tingkat profitabilitas yang lebih tinggi maka audit report lag akan lebih pendek dibandingkan perusahaan dengan tingkat 
profitabilitas yang lebih rendah. Perusahaan yang melaporkan kerugian mungkin akan meminta auditor untuk mengatur waktu auditnya lebih lama dibandingkan biasanya. Sebaliknya, jika perusahaan melaporkan laba yang tinggi, maka perusahaan berharap laporan keuangan auditan dapat diselesaikan secepatnya sehingga good news tersebut dapat disampaikan kepada para investor dan pihak-pihak yang berkepentingan lainnya. Hasil penelitian (Sastrawan \& Latrini, 2016) menyatakan profitabilitas berpengaruh negatif terhadap audit report lag. Hasil penelitian yang sejalan juga didapatkan oleh (Pramaharjan \& Cahyonowati, 2015) yang menyatakan profitabilitas berpengaruh negatif terhadap audit report lag.

$\mathrm{H}_{2}$ : Profitabilitas berpengaruh negatif terhadap audit report lag.

Pengaruh Solvabilitas Terhadap Audit Report Lag

Analisa solvabilitas mengukur sejauh mana perusahaan dapat melunasi semua kewajibannya, baik jangka pendek maupun jangka panjang dengan menggunakan aktiva yang ada. Proporsi yang besar dari hutang terhadap total aktiva akan meningkatkan kecenderungan kerugian dan dapat meningkatkan kehati-hatian dari auditor terhadap laporan keuangan yang sedang di audit. Kehatihatian ini dapat berpengaruh terhadap jangka waktu penyelesaian audit dan kepatuhan perusahaan dalam melaporkan laporan keuangannya secara tepat waktu, karena perusahaan cenderung akan menunda pelaporan keuangan jika ditemukan fakta bahwa perusahaan kesulitan untuk membayar hutang-hutangnya. Hal itu dilakukan untuk menjaga investor yang ada untuk tidak menarik dananya terlebih dahulu dan mempertahankan harga saham yang dimiliki perusahaan. Hal ini sesuai dengan penelitian yang dilakukan olah (Sastrawan \& Latrini, 2016) menyebutkan bahwa solvabilitas berpengaruh positif terhadap audit report lag.

$\mathrm{H}_{3}$ : Solvabilitas berpengaruh positif terhadap audit repot lag.

Pengaruh Kualitas Audit Terhadap Audit Report Lag

Kompetensi keahlian dan kemampuan auditor maupun fasilitas, sistem dan prosedur pengauditan yang digunakan the big four jauh memiliki nilai lebih dibandingkan non-big four sehingga mereka dapat menyelesaikan pekerjaan audit lebih efektif dan efisien. Kualitas jasa audit dari suatu KAP tentunya akan berimbas pada rentang waktu penyelesaian audit, reputasi KAP akan terjaga apabila KAP mampu memberikan kualitas jasa terbaik yang dibarengi dengan waktu penyelesaian audit yang cepat. The big four umumnya memiliki sumber daya yang lebih besar, baik itu dari segi kompetensi, keahlian, dan kemampuan auditor maupun fasilitas, sistem dan prosedur pengauditan yang digunakan dibandingkan non big four sehingga mereka dapat menyelesaikan pekerjaan audit lebih efektif dan efisien. Logikanya, perusahaan yang di audit oleh the big four akan memiliki waktu (audit report lag) lebih singkat ketimbang perusahaan yang di audit oleh non big four. Penelitian yang dilakukan oleh (Karang et al., 2015) menyatakan kualitas audit berpengaruh negatif terhadap audit report lag.

$\mathrm{H}_{4}$ : kualitas audit berpengaruh negatif pada Audit Report Lag

Opini audit berpengaruh negatif terhadap Audit Report Lag

Opini Audit adalah pendapat yang diberikan oleh auditor atas laporan keuangan klien yang telah di audit. Perusahaan yang mendapatkan opini unqualified opinion cenderung mempublikasikan laporan keuangan tepat waktu. Perusahaan yang mendapatkan opini audit selain unqualified opinion akan memiliki rentang audit report lag yang lebih lama daripada perusahaan yang mendapatkan unqualified opinion. Perusahaan yang mendapatkan selain unqualified opinion akan membutuhkan waktu yang lama dalam mempublikasikan laporan keuangannya karena auditor membutuhkan waktu untuk negosiasi dengan klien dan berkonsultasi pada auditor yang lebih senior.

(Tiono \& JogiC, 2013) menyatakan fenomena ini dapat terjadi karena proses pemberian pendapat qualified tersebut melibatkan negosiasi dengan klien, konsultasi dengan partner audit yang lebih senior atau staf teknis lainnya dan perluasan lingkup audit. Selain itu, auditor independen itu sendiri harus memiliki sikap hati-hati agar dapat mempertanggungjawabkan opini yang telah dibuat kepada pemakai laporan keuangan. Kadangkala kehati-hatian tersebut juga dapat memperpanjang lamanya audit report lag. Penelitian yang dilakukan oleh Andika (2015) menyatakan opini audit berpengaruh negatif terhadap audit report lag.

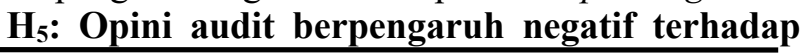




\section{Audit Report Lag \\ Pengaruh Komite Audit Terhadap Audit Report Lag}

Komite audit merupakan sebuah komite yang dibentuk oleh dewan komisaris yang berguna untuk membantu dewan komisaris dalam melaksanakan tugasnya serta meninjau kinerja auditor independen. (Apriyani, 2011) mengatakan bahwa opini audit berpengaruh secara negatif terhadap audit report lag. Hal tersebut menunjukan bahwa suatu anggota komite audit yang lebih banyak akan meningkatkan pengawasan terhadap penyusunan

\section{METODE PENELITIAN}

Lokasi penelitian dilakukan pada Perusahaan Pertambangan yang terdaftar di Bursa Efek Indonesia (BEI) tahun 2016-2018 dengan mengakses situs resmi Bursa Efek Indonesia di www.idx.co.id.

\section{Definisi Operasional Variabel Audit Report Lag}

Variabel ini diukur secara kuantitatif dalam jumlah hari yang dihitung dari jangka waktu penyelesaian audit terhadap laporan keuangan berdasarkan perbedaan waktu antara tanggal penutupan tahun buku per 31 Desember dengan tanggal diterbitkannya laporan audit. Skala pengukuran yang digunakan dalam penelitian ini adalah skala rasio.

Audit Report Lag = Tanggal Laporan Audit Tanggal Laporan Keuangan

\section{Ukuran Perusahaan}

Ukuran perusahaan diukur dengan menggunakan total aset perusahaan dengan menggunakan log size (natural logaritma) untuk menghaluskan besarnya angka dan menyamarkan ukuran regresi.

Ukuran Perusahaan $=$ Ln(total aktiva)

\section{Profitabilitas}

Rasio yang menggambarkan kemampuan perusahaan mendapatkan laba melalui semua kemampuan, dan sumber yang ada seperti kegiatan penjualan, kas, modal, jumlah karyawan, jumlah cabang, dan sebagainya (Harahap, 2008).

Return On Asset $(\mathrm{ROA})=\frac{\text { laba bersih }}{\text { total aktiva }}$

\section{Solvabilitas}

Rasio ini merupakan perbandingan antara total hutang dengan total aktiva. Sehingga rasio ini menunjukkan sejauh mana hutang dapat ditutupi laporan keuangan perusahaan sehingga auditor dapat menyelesaikan pekerjaan auditnya secara cepat. Penelitian yang dilakukan oleh (Gunarsa, Cahya dan Putri, 2017) menyatakan komite audit berpengaruh negatif terhadap audit report lag. Konsisten dengan penelitian dari (Santoso, 2018), (Isnania et al., 2018) menyatakan komite audit berpengaruh negatif terhadap audit report lag.

H6: Komite Audit berpengaruh negatif pada Audit Report Lag

oleh aktiva. Menurut (Sawir, 2009) debt to total asset merupakan rasio yang memperlihatkan proporsi antara kewajiban yang dimiliki dan seluruh kekayaan yang dimiliki.

Debt to Equity Ratio (DER)= $=\frac{\text { Total Hutang }}{\text { Total Ekuitas }}$

\section{Kualitas Audit}

Penelitian ini menilai kualitas audit berdasarkan ukuran KAP. Ukuran KAP dilihat dari apakah KAP tersebut adalah the big four atau non big four. Dalam penelitian ini pengukuran yang digunakan yaitu dengan Variabel dummy, 1 = The Big Four, 0 = Non Big Four

\section{Opini Audit}

Opini auditor dalam penelitian ini diukur dengan melihat jenis opini yang diberikan oleh auditor independen terhadap laporan keuangan perusahaan yang terdaftar di BEI. Dalam penelitian ini pengukuran yang digunakan yaitu dengan Variabel dummy, 1 = opini audit wajar tanpa pengecualian, $0=$ selain opini audit wajar tanpa pengecualian.

\section{Komite Audit}

Variabel ini diukur dengan menggunakan jumlah anggota komite audit yang terdapat pada suatu perusahaan. Variabel jumlah anggota komite audit dilambangkan dengan KA. (Pramaharjan \& Cahyonowati, 2015)

Komite audit $=\sum$ Jumlah Komite Audit

\section{Populasi dan Sampel}

Populasi dalam penelitian ini adalah seluruh perusahaan pertambangan yang terdaftar di Bursa Efek Indonesia periode 2016-2018. Jumlah populasi perusahaan manufaktur yang terdaftar di Bursa Efek Indonesia periode 2016-2018 adalah 
147 perusahaan. Metode pengambilan sampel yang digunakan adalah purposive sampling, yaitu teknik penentuan sampel dengan pertimbangan tertentu, sehingga didapat jumlah sampel dalam penelitian ini sebanyak 123 perusahaan pertambangan yang terdaftar di Bursa Efek Indonesia periode 20162018.

\section{Metode Pengumpulan Data}

Untuk menunjang landasan teori penelitian dan mendapatkan data-data yang diperlukan, peneliti menggunakan metode pengumpulan data berupa studi pustaka dan studi dokumentasi. Pengumpulan data dalam penelitian ini diperoleh dengan mengakses website Bursa Efek Indonesia yaitu www.idx.co.id.

\section{Teknik Analisis Data Statistik Deskriptif}

Statistik deskriptif merupakan statistik yang menggambarkan fenomena atau karakteristik dari data. Karakteristik data yang digambarkan adalah karakteristik distribusinya. Statistik ini menyediakan nilai frekuensi, pengukur tendensi pusat, disperse dan pengukuran bentuk (Hartono, 2015).

\section{Uji asumsi klasik}

Uji asumsi klasik dilakukan untuk memastikan bahwa sampel yang diteliti terhindar dari gangguan normalitas, multikolonieritas, autokorelasi, dan heteroskedastisitas.

\section{Analisis regresi linier berganda}

Menurut (Ghozali, 2016), regresi linier berganda adalah hubungan secara linier antara dua atau lebih variabel independen dengan variabel dependen. Persamaan regresi linier berganda dapat dirumuskan sebagai berikut:

$\mathrm{ARL}=\mathrm{a}+\mathrm{b}_{1}(\mathrm{UP})+\mathrm{b}_{2}(\mathrm{ROA})+\mathrm{b}_{3}(\mathrm{DER})+\mathrm{b}_{4}(\mathrm{KA})+\mathrm{b}_{5}(\mathrm{O}$ A) $+b_{6}(\mathrm{KAU})+\mathrm{e}$

\section{HASIL DAN PEMBAHASAN}

Statistik Deskriptif
Keterangan :

$\mathrm{ARL}=$ Audit Report Lag

$\mathrm{UP}=$ Ukuran perusahaan

ROA $=$ Profitabilitas

$\mathrm{DER}=$ Solvabilitas

$\mathrm{KA}=$ Kualitas audit

$\mathrm{OA}=$ Opini auditor

$\mathrm{KAU}=$ Komite Audit

$\mathrm{e}=$ Standart error

\section{Uji Koefisien Determiasi $\left(R^{2}\right)$}

Uji koefisien determinasi $\left(\mathrm{R}^{2}\right)$ pada intinya mengukur seberapa jauh kemampuan model dalam menerangkan variasi dependen (Ghozali, 2016).

\section{Uji Signifikansi Simultan (Uji Statistik F)}

Uji F dilakukan untuk menunjukan apakah variabel independen atau bebas yang dimasukan dalam model mempunyai pengaruh secara bersama-sama terhadap variabel dependen. Uji $F$ dapat juga dilakukan dengan melihat nilai signifikan $F$ pada output hasil regresi menggunakan SPSS dengan tingkat signifikansi $0.05 \quad(a=5 \%)$. Jika nilai signifikansi lebih besar dari a maka hipotesis ditolak, yang berarti model regresi tidak fit. Jika nilai signifikansi lebih kecil dari a maka hipotesis diterima. Yang berarti bahwa model regresi fit. (Ghozali, 2016)

\section{Uji Signifikansi Parameter Individual (Uji Statistik t)}

Menurut (Ghozali, 2016) Uji statistik t pada dasarnya menunjukkan pengaruh satu variabel independen secara parsial dalam menerangkan variable-variabel dependen. Jika signifikansi $\mathrm{t} \leq$ 0,05 . Hal ini berarti bahwa variabel bebas secara parsial berpengaruh signifikan terhadap variabel terkait. Sedangkan jika signifikansi t $>0,05$. Hal ini berarti bahwa variabel bebas secara parsial tidak berpengaruh terhadap variabel terikat. 
Tabel 1

Hasil statistik deskriptif

\begin{tabular}{|l|c|r|r|r|r|}
\hline & $\mathrm{N}$ & Minimum & Maximum & \multicolumn{1}{c|}{ Mean } & $\begin{array}{c}\text { Std. } \\
\text { Deviation }\end{array}$ \\
\hline UP & 123 & 25.57 & 32.24 & 29.3493 & 1.56571 \\
ROA & 123 & -6.87 & 1.00 & -.0395 & .69168 \\
DER & 123 & -15435.38 & 34.06 & -127.3460 & 1392.05382 \\
KA & 123 & .00 & 1.00 & .4309 & .49723. \\
OA & 123 & .00 & 1.00 & .9593 & .19829 \\
KAU & 123 & 2.00 & 6.00 & 3.1707 & .61012 \\
ARL & 123 & 31.00 & 354.00 & 88.2520 & 46.62206 \\
Valid N & 123 & & & & \\
(listwise) & & & & & \\
\hline
\end{tabular}

Sumber Lampiran 3, Data diolah (2020).

Berdasarkan Tabel 5.1 gambaran tentang distribusi data dapat dilihat bahwa Variabel Ukuran Perusahaan (UP) memiliki nilai minimum 25,57 dan maksimum 32,24 dengan rata-rata 29,3493 dan standar deviasi 1,56571. Variabel profitabilitas (ROA) memiliki nilai minimum $-6,87$ dan maksimum 1,00 dengan rata-rata $-0,0395$ dan standar deviasi 0,69168. Variabel Solvabilitas (DER) memiliki nilai minimum $-15435,38$ dan maksimum 34,06 dengan rata-rata $-127,3460$ dan standar deviasi 1392,05382. Kualitas Audit (KA) memiliki nilai minimum 0,00 dan maksimum 1,00 dengan rata-rata 0,4309 dan standar deviasi 0,49723. Opini Audit (OA) memiliki nilai minimum 0,00 dan maksimum 1,00 dengan ratarata 0,9593 dan standar deviasi 0,19829 . Komite Audit (KAU) memiliki nilai minimum 2,00 dan maksimum 6,00 dengan rata-rata 3,1707 dan standar deviasi 0,61012. Variabel audit report lag (ARL) memiliki nilai minimum 31,00 dan maksimum 354,00 dengan rata-rata 88,2520 dan standar deviasi 46,62206.

\section{Analisis Regresi Linear Berganda}

Tabel 2

Hasil Uji Analisis Regresi Linier Berganda

\begin{tabular}{|c|c|c|c|c|c|}
\hline \multirow[b]{2}{*}{ Model } & \multicolumn{2}{|c|}{$\begin{array}{l}\text { Unstandardized } \\
\text { Coefficients }\end{array}$} & \multirow{2}{*}{$\begin{array}{c}\text { Unstandardized } \\
\text { Coefficients } \\
\text { Beta }\end{array}$} & \multirow[b]{2}{*}{$\mathrm{t}$} & \multirow[t]{2}{*}{ Sig. } \\
\hline & B & $\begin{array}{l}\text { Std. } \\
\text { Error }\end{array}$ & & & \\
\hline $\begin{array}{l}1 \\
\text { (Constant) }\end{array}$ & .553 & .412 & & 1.341 & .182 \\
\hline UP & 1.220 & .138 & .691 & 8.830 & .000 \\
\hline ROA & -.004 & .024 & -.010 & -.148 & .883 \\
\hline DER & -.050 & .021 & -.155 & 2.372 & .019 \\
\hline KA & -.193 & .073 & -.176 & .2642 & .009 \\
\hline OA & -.194 & .183 & -.073 & 1.059 & .292 \\
\hline KAU & -.013 & .218 & -.004 & -.058 & .954 \\
\hline
\end{tabular}

a. Dependent Variabel: ARL

Sumber : Lampiran 5, Data diolah (2020). 
Berdasarkan Tabel 5.6 dapat ditulis persamaan regresi linier berganda sebagai berikut:

$\mathrm{ARL}=0,553+1,220 \mathrm{UP}-0,004 \mathrm{ROA}-0,050$ DER - 0,193 KA - 0,194 OA -0,013 KAU

Nilai konstanta sebesar 0,553 artinya apabila ukuran perusahaan (UP), profitabilitas (ROA), solvabilitas (DER), komite audit (KA), opini audit (OA), kualitas audit (KAU) sama dengan 0 (konstan), maka besarnya nilai audit report lag (ARL) adalah sebesar 0,553.

Nilai koefisien regresi untuk variabel ukuran perusahaan (UP) sebesar 1,220 dengan tingkat signifikansi sebesar 0,000 . Hal ini menandakan bahwa setiap peningkatan ukuran perusahaan bertambah satu satuan akan mengakibatkan kenaikan pada audit report lag (ARL) sebesar 1,220 dengan asumsi variabel bebas lainnya adalah konstan atau sama dengan nol.

Nilai koefisien regresi untuk variabel profitabilitas (ROA) sebesar -0,004 dengan tingkat signifikansi sebesar 0,883 . Hal ini menandakan bahwa setiap peningkatan profitabilitas bertambah satu satuan akan mengakibatkan penurunan pada audit report lag (ARL) sebesar -0,004 dengan asumsi variabel bebas lainnya adalah konstan atau sama dengan nol.

Nilai koefisien regresi untuk variabel solvabilitas (DER) sebesar -0,050 dengan tingkat signifikansi sebesar 0,019. Hal ini menandakan bahwa setiap peningkatan solvabilitas bertambah satu satuan akan mengakibatkan penurunan pada audit report lag (ARL) sebesar -0,050 dengan asumsi variabel bebas lainnya adalah konstan atau sama dengan nol.

Nilai koefisien regresi untuk variabel kualitas audit (KA) sebesar -0,193 dengan tingkat signifikansi sebesar 0,009. Hal ini menandakan bahwa setiap peningkatan kualitas audit bertambah satu satuan akan mengakibatkan penurunan pada audit report lag (ARL) sebesar -0,193 dengan asumsi variabel bebas lainnya adalah konstan atau sama dengan nol.

Nilai koefisien regresi untuk variabel opini audit (OA) sebesar -0,194 dengan tingkat signifikansi sebesar 0,292. Hal ini menandakan bahwa setiap peningkatan opini audit bertambah satu satuan akan mengakibatkan penurunan pada audit report lag (ARL) sebesar -0,194 dengan asumsi variabel bebas lainnya adalah konstan atau sama dengan nol.

Nilai koefisien regresi untuk variabel komite audit (KAU) sebesar -0,013 dengan tingkat signifikansi sebesar 0,954. Hal ini menandakan bahwa setiap peningkatan komite audit bertambah satu satuan akan mengakibatkan penurunan pada audit report lag (ARL) sebesar -0,013 dengan asumsi variabel bebas lainnya adalah konstan atau sama dengan nol.

Penelitian ini sudah memenuhi Uji Asumsi Klasik diantaranya Uji Normalitas, Uji Multikolinearitas, Uji Heteroskedastisitas, dan Uji Autokolerasi. Model regresi ini sudah layak uji ditandai dengan hasil uji $\mathrm{F}$ dapat dijelaskan bahwa nilai signifikansinya sebesar 0,000 lebih kecil dari 0,05 . Hal ini menunjukkan bahwa ukuran perusahaan (UP), profitabilitas (ROA), solvabilitas (DER), kualitas audit (KA), opini audit (OA), dan komite audit (KAU) berpengaruh secara simultan terhadap audit report lag (ARL) pada perusahaan pertambangan yang terdaftar di Bursa Efek Indonesia tahun 2016-2018. Nilai koefisien determinasi (Adjusted $R$ Square) pada penelitian ini diperoleh nilai sebesar 0,509 atau sebesar 50,9 persen. Hal ini berarti audit report lag mampu dijelaskan sebesar 50,9 persen oleh variabel ukuran perusahaan, profitabilitas, solvabilitas, kualitas audit, opini audit dan komite audit sedangkan sisanya 49,1 persen dipengaruhi oleh variabelvariabel lain diluar model penelitian ini.

\section{Pengaruh ukuran perusahaan terhadap Audit Report Lag}

Hipotesis pertama menyatakan bahwa ukuran perusahaan berpengaruh negatif terhadap audit report lag. Berdasarkan hasil analisis nilai koefisien 1,220 , nilai $\mathrm{t}$ hitung sebesar 8,830 dengan nilai signifikansi 0,000 dimana nilai tersebut lebih kecil dari 0,05 . Hasil analisis menyatakan bahwa ukuran perusahaan berpengaruh positif terhadap audit report lag, sehingga hipotesis pertama (H1) ditolak. Hal ini berarti besar kecil ukuran perusahaan berpengaruh terhadap audit report lag. Hasil penelitian ini mendukung penelitian yang dilakukan oleh (Delia Alvorina Kalinggajaya, 2018) yang menunjukkan bahwa ukuran perusahaan memiliki pengaruh positif dan signifikan terhadap audit report lag. Hal ini disebabkan karena semakin besar total aset yang dimiliki oleh suatu perusahaan, maka akan menyelesaikan audit lebih lama dibandingkan dengan perusahaan yang mempunyai total aset lebih kecil, dikarenakan jumlah sampel yang harus diambil semakin besar dan semakin 
banyak prosedur audit yang harus ditempuh. Jika ukuran sebuah perusahaan semakin besar maka perusahaan tersebut semakin dikenal oleh masyarakat luas. Dengan semakin dikenalnya perusahaan tersebut maka tuntutan transparansi juga semakin besar. Maka kebutuhan untuk menyampaikan laporan keuangan juga semakin dibutuhkan.

\section{Pengaruh profitabilitas terhadap Audit Report Lag}

Hipotesis kedua menyatakan bahwa profitabilitas berpengaruh negatif terhadap audit report lag. Berdasarkan hasil analisis nilai koefisien sebesar $-0,004$, nilai $t$ hitung sebesar $-0,148$ dengan nilai signifikansi 0,883 dimana nilai tersebut lebih besar dari 0,05. Hasil analisis menyatakan bahwa profitabilitas tidak berpengaruh terhadap audit report lag, sehingga hipotesis kedua (H2) ditolak. Hasil penelitian ini mendukung penelitian (Chasanah \& Sagoro, 2017), (Delia Alvorina Kalinggajaya, 2018) yang menemukan bahwa profitabilitas tidak berpengaruh signifikan terhadap audit report lag. Profitabilitas tidak mempengaruhi audit report lag, hal ini disebabkan karena proses dalam pengauditan perusahaan yang memiliki tingkat profitabilitas kecil tidak memiliki perbedaan dengan proses pengauditan perusahaan yang memiliki tingkat profitabilitas besar. Hal ini dikarenakan adanya ketentuan dari Otoritas Jasa Keuangan yang mewajibkan setiap perusahaan yang terdaftar di Bursa Efek Indonesia untuk melaporkan laporan keuangan tahunnya selambatlambatnya 120 hari setelah tanggal neraca. Setiap perusahaan, baik yang memiliki profitabilitas tinggi maupun rendah cenderung tidak ingin mengambil resiko dan memilih untuk melaporkan laporan keuangannya secara tepat waktu.

\section{Pengaruh solvabilitas terhadap Audit Report Lag}

Hipotesis ketiga menyatakan bahwa solvabilitas berpengaruh positif terhadap audit report lag. Berdasarkan hasil analisis nilai koefisien sebesar $-0,050$, nilai t hitung sebesar $-2,372$ dengan nilai signifikansi 0,019 dimana nilai tersebut lebih kecil dari 0,05 . Hasil analisis menyatakan bahwa Solvabilitas berpengaruh negatif terhadap audit report lag, sehingga hipotesis kedua $(\mathrm{H} 3)$ ditolak. Hasil penelitian yang menunjukkan bahwa solvabilitas berpengaruh negatif terhadap audit report lag artinya semakin tinggi solvabilitas, maka akan mengurangi rentang waktu yang dibutuhkan auditor dalam mengaudit laporan keuangan. Hal ini disebabkan karena perusahaan yang solvable mampu membayar utang-utangnya dengan aset yang dimilikinya. Dengan tingkat kemampuan membayar utang yang baik, perusahaan memiliki kepercayaan diri untuk segera menampilkan laporan keuangannya, hal tersebut akan mempengaruhi percepatan proses audit. Selain itu perusahaan melalui manajemen dengan sukarela mengungkapkan hutang dan dokumen pendukungnya kepada auditor untuk memudahkan prosedur audit yang dilakukan, maka dapat membantu dalam mempercepat proses audit. Hasil penelitian ini konsisten dengan penelitian (Vidiana, 2019) yang menyatakan solvabilitas berpengaruh negatif terhadap audit report lag.

\section{Pengaruh kualitas audit terhadap Audit Report Lag}

Hipotesis keempat menyatakan bahwa kualitas audit berpengaruh negatif terhadap audit report lag. Berdasarkan hasil analisis nilai koefisien sebesar 0,193 , nilai t hitung sebesar $-2,642$ dengan nilai signifikansi 0,009 dimana nilai tersebut lebih kecil dari 0,05 . Hasil analisis menyatakan bahwa kualitas audit berpengaruh negatif terhadap audit report lag, sehingga hipotesis kedua (H4) diterima. Kualitas audit dalam penelitian ini di proksi dari KAP yang digunakan oleh perusahaan. Hasil penelitian ini mengindikasikan bahwa semakin tinggi kualitas audit maka rentang waktu penyelesaian audit yang dibutuhkan auditor akan semakin pendek. Kualitas audit dari suatu KAP tentunya akan berimbas pada rentang waktu penyelesaian audit, reputasi KAP akan terjaga apabila KAP mampu memberikan kualitas jasa terbaik yang dibarengi dengan waktu penyelesaian audit yang cepat. The big four umumnya memiliki sumber daya yang lebih besar, baik itu dari segi kom.petensi, keahlian, dan kemam.puan auditor mau.pun fasi.litas, sist.em dan prosedur peng.auditan yang digunakan dibandingkan non big four sehingga mer.eka dapat menyel.esaikan peke.rjaan audit lebih efe.ktif dan efi.sien. Hasil penelitian ini sejalan dengan penelitian yang dilakukan oleh (Karang et al., 2015) yang menyatakan kualitas audit bepengaruh negatif terhadap audit report lag. 


\section{Pengaruh opini audit terhadap Audit Report Lag}

Hipotesis kelima menyatakan bahwa opini audit berpengaruh negatif terhadap audit report lag. Berdasarkan hasil analisis nilai koefisien sebesar 0,194 , nilai t hitung sebesar $-1,059$ dengan nilai signifikansi 0,292 dimana nilai tersebut lebih besar dari 0,05 . Hasil analisis menyatakan bahwa opini audit tidak berpengaruh terhadap audit report lag, sehingga hipotesis kedua (H5) ditolak. Dalam penelitian ini menunjukkan bahwa jenis opini audit yang diberikan oleh auditor tidak mempengaruhi cepat lambatnya jangka waktu audit report lag. Opini audit adalah wewenang dari kantor akuntan publik sebagai lembaga yang independen dan bertanggung jawab ke publik untuk mengeluarkan opini berdasarkan laporan keuangan yang diaudit. Tidak semua perusahaan yang mendapat opini selain unqualified opinion mengalami proses audit yang lebih panjang dari pada perusahan yang memperoleh unqualified opinion. Hal ini disebabkan auditor sudah mendapatkan cukup bukti untuk memperkuat opininya bahwa laporan keuangan perusahaan tersebut tidak memenuhi syarat untuk mendapatkan unqualified opinion, sehingga perusahaan yang memperoleh opini selain unqualified opinion tetap dapat melaporkan hasil auditnya tepat waktu. Hasil penelitian ini sejalan dengan penelitian yang dilakukan oleh (Apitaningrum, 2017) yang menyatakan opini audit tidak berpengaruh terhadap audit report lag.

\section{Pengaruh komite audit terhadap Audit Report Lag}

Hipotesis keenam menyatakan bahwa komite audit berpengaruh negatif terhadap audit report lag.

\section{KESIMPULAN DAN SARAN}

Berdasarkan hasil analisis dan uraian pada bab sebelumnya, maka dapat diambil kesimpulan sebagai berikut:

1. Ukuran perusahaan berpengaruh positif terhadap audit report .

2. Profitabilitas (ROA) tidak berpengaruh terhadap audit report.

3. Solvabilitas (DER) berpengaruh negatif terhadap audit report lag.

4. Kualitas audit (KA) berpengaruh negatif terhadap audit report lag.

5. Opini audit (OA) tidak berpengaruh terhadap audit report .
Berdasarkan hasil analisis, nilai koefisien sebesar 0,013 , nilai $t$ hitung sebesar $-0,058$ dengan nilai signifikansi 0,954 dimana nilai tersebut lebih besar dari 0,05 . Hasil analisis menyatakan bahwa kualitas audit tidak berpengaruh terhadap audit report lag, sehingga hipotesis kedua (H6) ditolak. Hasil penelitian ini menyimpulkan bahwa komite audit yang banyak atau sedikit tidak berpengaruh terhadap terhadap audit report lag. Jumlah anggota komite audit dalam suatu perusahaan bukan menjadi salah satu faktor lamanya rentan waktu yang di butuhkan auditor dalam mengaudit laporan keuangan. Hal ini disebabkan karena perusahaan tersebut hanya ingin memenuhi peraturan yang ada pada peraturan otoritas jasa keuangan nomor 55 /POJK.04/2015 pasal 4 mengenai jumlah minimal komite audit, sehingga tugas dari komite audit tidak optimal. Dalam penelitian ini ada beberapa perusahaan yang memiliki komite audit melebihi persyaratan minimal namun melaporkan laporan keuangan auditan lebih lama seperti: PT. Bayan Resources Tbk tahun 2016. Begitu juga sebaliknya, ada perusahaan yang memiliki sedikit komite audit justru melaporkan laporan keuangan auditan lebih cepat seperti: PT. Surya Esa Perkasa Tbk tahun 2016. Tugas utama komite audit adalah sebagai pengawas independen dalam penyusunan laporan auditor independen sehingga wewenang dalam penerbitan laporan audit suatu perusahaan masih sebagian besar ditentukan oleh auditor sebagai pengaudit laporan keuangan. Hasil penelitian ini sejalan dengan penelitian Arisha (2019) yang menyatakan komite audit tidak berpengaruh terhadap audit report lag.

6. Komite audit (KAU) tidak berpengaruh terhadap audit report .

Penelitian ini hanya meneliti variabel ukuran perusahaan, profitabilitas, solvabilitas, kualitas audit, opini audit, dan komite audit. Selain itu, penelitian ini menggunakan periode yang pendek hanya 3 (tiga tahun dan hanya menggunakan perusahaan pertambangan yang terdaftar di Bursa Efek Indonesia (BEI) Saran yang dapat disampaikan peneliti bagi Bagi penelitian selanjutnya dapat menambah variabel independen lainnya selain dari variabel independen yang telah diteliti seperti pergantian auditor dan dewan 
komisaris yang diperkirakan dapat mempengaruhi

\section{DAFTAR PUSTAKA}

Andika, Windu. 2015. Pengaruh Profitabilitas, Solvabilitas, Likuiditas, Ukuran Perusahaan, Opini Audit terhadap Audit Report Lag pada Perushaan Jasa yang Terdaftar di Bursa Efek Indonesia tahun 2011-2013. Skripsi. Universitas Sanata Dharma. Yogyakarta.

Arisha, Wia. 2019. Pengaruh Solvabilitas, Profitabilitas, Ukuran Perusahaan, Komite Audit dan Reputasi Auditor Terhadap Audit Report Lag tahun 2016-2018. Skripsi. Universitas Mahasaraswati. Denpasar. Bali.

Apitaningrum, A. (2017). Pengaruh Pergantian Auditor, Opini Audit, Ukuran Perusahaan, dan Laba Rugi Terhadap Audit Report Lag (Studi Empiris Pada Perusahaan Manufaktur yang Terdaftar di Bursa Efek Indonesia Periode 2011-2015). Jurnal Ekonimi Dan Bisnis Universitas Muhammadiyah Surakarta.

Apriyani, N. N. (2011). Pengaruh Solvabilitas, Opini Auditor, Ukuran Kap, Dan Komite Audit Terhadap Audit Delay. Phys. Rev. E.

Arens, A, Elder, Randal J, Beasley, Mark S, dan Jusuf, A. A. (2011). Jasa Audit dan Assurance Pendekatan Terpadu (Adaptasi Indonesia). In Jakarta: Salemba Empat.

Badan Pengawas Pasar Modal dan Lembaga Keuangan (BAPEPAM LK). Keputusan Ketua BAPEPAM LK No. KEP-431/BL/2012 tentang Penyampaian Laporan Tahunan Emiten atau Perusahaan Publik.

Bursa Efek Indonesia, Laporan Keuangan Tahunan 2016, 2017, dan 2018. (diakses di http://www.idx.co.id).

Chaplin, J. P. (2014). Kamus Lengkap Psikologi. Penerjemah. In Jakarta: PT Raja Grafindo Persada.

Chasanah, I. U., \& Sagoro, E. M. (2017). Faktor-Faktor Yang Berpengaruh Terhadap Audit Report Lag Pada Perusahaan LQ-45. Jurnal Profita.

Delia Alvorina Kalinggajaya. (2018). Pengaruh Profitabilitas, Solvabilitas, Ukuran Kap, Opini Audit Dan Ukuran Perusahaan Terhadap Audit Report Lag Pada Perusahaan Manufaktur. New England Journal of Medicine.

Ghozali, I. (2016). Ghozali, Imam. 2016. Aplikasi Analisis Multivariate dengan Program SPSS. Semarang: Badan Penerbit UNDIP. In Analisis Multivariate dengan Program SPSS.

Gunarsa, Cahya dan Putri, D. (2017). "Pengaruh Komite Audit, Independensikomite Audit, Dan Profitabilitas Terhadap Audit Report Lagdi Perusahaan Manufaktur.” E-Jurnal . Universitas Udayana, Vol.20.2., 1672-1703.

Hartono, J. (2015). Konsep dan Aplikasi Structural Equation Modeling (SEM) Berbasis Varian dalam Penelitian Bisnis. Public Administration Review.

Isnania, S. A., Sukarmanto, E., \& Maemunah, M. (2018). Pengaruh komite audit, dewan komisaris independen dan reputasi kap terhadap audit report lag. Prosiding Akuntansi.

Jensen, M. C., \& Meckling, W. H. (1976). Theory of the firm: Managerial behavior, agency costs and ownership audit report lag.

structure. Journal of Financial Economics. https://doi.org/10.1016/0304-405X(76)90026-X

Karang, N. M. D. U., Yadnyana, I. K., \& Ramantha, I. W. (2015). Pengaruh Faktor Internal dan Eksternal Pada Audit Delay. E-Jurnal Ekonomi Dan Bisnis Universitas Udayana.

Peraturan Otoritas Jasa Keuangan (POJK) Nomor 55 /POJK.04/2015 Tentang Pembentukan dan Pedoman Pelaksanaan Kerja Komite Audit (diakses pada www.ojk.go.id)

Peraturan Otoritas Jasa Keuangan Nomor (PJOK) 29/POJK.04/2016 Tentang Laporan Tahunan Emiten atau Perusahaan Publik (diakses pada www.ojk.go.id)

Pramaharjan, B., \& Cahyonowati, N. (2015). Faktor Faktor Yang Berpengaruh Terhadap Audit Report Lag Pada Perusahaan Manufaktur. Diponegoro Journal of Accounting.

Rizkyllah, P. (2018). Pengaruh Opini Audit, Komite Audit, dan Umur Perusahaan Terhadap Audit Report Lag pada Perusahaan yang Terdaftar di Bursa Efek Indonesia Tahun 2011-2016. Skripsi.

Sabatini, S. N., \& Vestari, M. (2019). Nilai Persediaan, Aset Tetap, Ukuran Perusahaan, Kualitas Audit, Dan Audit Tenure Terhadap Audit Report Lag. Econbank: Journal of Economics and Banking. https://doi.org/10.35829/econbank.v1i2.46

Santoso, B. (2018). Pengaruh Ukuran Komite Audit, Solvabilitas, dan Profitabilitas Terhadap Audit Report Lag dengan Audit Tenure Sebagai Variable Moderasi pada Perusahaan Food \& Beverages di BEI Tahun 2012 S . D 2016. E-Jurnal Akuntansi Esa Unggul.

SAPUTRI, O. D. (2014). Analisis Faktor-Faktor Yang Mempengaruhi Audit Delay. Jurnal Fakultas Ekonomi Dan Bisnis Universitas Diponegoro.

Sastrawan, I. P., \& Latrini, M. Y. (2016). Pengaruh Profitabilitas, Solvabilitas, Dan Ukuran Perusahaan Terhadap Audit Report Lag Pada Perusahaan Manufaktur. E-Jurnal Akuntansi Universitas Udayana.

Sawir. (2009). Analisis Kinerja Keuangan dan Perencanaan Keuangan Perusahaan PT. Gramedia Pustaka Utama, Jakarta. E-Jurnal Manajemen Universitas Udayana.

Sujarweni, V. W. (2017). Analisis Laporan Keuangan teori, aplikasi, dan hasil penelitian. In Analisis Laporan Keuangan teori, aplikasi, dan hasil penelitian.

Tiono, I., \& JogiC, Y. (2013). Faktor-Faktor yang Mempengaruhi Audit Report Lag di Bursa Efek Indonesia. Business Accounting.

Vidiana, I. (2019). Pengaruh Kompetensi, Aktivitas, dan Size Komite Audit serta Solvabilitas terhadap Audit Report Lag. E-Jurnal. STIE Yayasan Keluarga Pahlawan Negara. Yogyakarta. 